\title{
The Struggling of Onan as Gathering Space in Urban Transformation
}

\author{
Morida Siagian \\ Department of Architecture, Faculty of Engineering, Universitas Sumatera Utara, Jl. Universitas Kampus USU \\ Medan 20155 \\ Email: pohontepiair@gmail.com,morida@usu.ac.id
}

\begin{abstract}
Cities in different parts of the world compete into an advanced city. The changes occur everywhere and change the city space as tangible and intangible. This phenomenon also occurs in Balige. Globalization has encouraged capitalists to bring modernity to the various corners of the Balige. The local spaces with the use value of living are appealing with modernity, causing the Balige city space to be dominated by abstract space with an exchanged value. However, the contradiction of the space did not succeed in affecting the intention of the Onan in Balige. This article aims to describe how the issue of space caused by the conflict between community life and capitalist in Balige can be completed. Using Lefebvre theory qualitative research, including literary studies, spatial observation, repeated interviews and documentation activities, the study find that a space where community diversity, the local way of life and the modernity carried by capitalists is mingled at the time of the Onan Balige. The transformation of space that occurs over time does not alter the existence of the Onan. The social, cultural, religious, political and economic values of the community are embraced by the establishment and sustainability of the space. Onan has become a space for local community struggle that is firmly attached to the community's memory until today.
\end{abstract}

Keywords: City, Identity, Onan, Space

\section{INTRODUCTION}

Space is an important part of human life's daily journey. Michel Foucault stated that the entire history of human life takes place in the space [1]. According to him space not only can be interpreted as a real form that has dimensions. But it is also interpreted as a space that brings together physical, mental and social spaces lifes. Similarly, Madanipour [2] stated that the space is abstract, has no boundaries, something is 'unlimited in extent'. Space is a result of social relationships and also one that gives the possibility of social relations in which there is a use value of living (value) [3]. Reciprocal relations between social relations and space are inseparable [4]. The city space can be analyzed by understanding the social relations. Space production is not detached from social life. Social relations is a force on the creation of space. The space also allows social relations. Lefebvre said that space is not just something produced, but it is also a means of production or 'forces of production'.
But in the development of the awareness, the space becomes an important part of the neglection. City planners play with abstract spaces, while the public do against absolute space. The Production of Space concept presented by Lefebvre was to explain how the destruction of the society occurs. The issue of space which is happening in modern cities is caused by the conflict between community life and capitalism. The contradiction between these two concents lies in the 'use value of living' that is owned by the community in everyday life and the 'exchange value of capitalism' that is brought by capitalist [5].

The recent development that takes place in various cities around the world further emphasizes the change that it does in the cities. The abstract space is the instrument of a power (a tool of power) of the capitalist and produced by capitalism. The power of capital owned by investors is the defining design and function of new spaces in accordance with their interests. The space is no longer seen as being ideal to animate existing and long-lasting human activity in it, but the space seen as a commodity that can bring profit and 
interest to the capital owners. Not only capitalist, the government also has a role in the transformation of the city space. Gottdiener said that government and private intervention in planning and development led to a transformation of a city. Because the sustainability of the capitalist depends on the ownership of the land, the two parties bring up abstract spaces.

Soja in his book Thirdspace [6] explained that abstract space is an instrument in the destruction of the society. As for social space, society is vital. Social space and abstract space are opposite. The contradiction between the two spaces is a contradiction between 'quantity' and 'quality', 'exchange value' and 'use value', 'space of consumption' and 'space of production'. The second conflict between these definition of this space is fundamental in modern society. In the event of conflicts and contradictions that occurred, arose a separation of spatial and social relations, the entry of government forces and capitalist intervention, the division of space relating to the separation of society according to social groups.

The struggle against contradictions creates new spaces as meeting places of the separation. These spaces become the meeting between the groups and the gathering of both values. The social spaces exist in a real life, meet the groups of people and varying values.

Soja said people in the city feel alienation and mystification in their daily lifes. Community needs to take action and struggle. Lefebvre believes that the space being used as a tool of struggle is a social space. The social space (lived space) is a medium that holds many sources of power. 'Lived space' or Thirdspace is 'the space of social struggle'.

\section{METHOD}

Onan Balige is one of the economic, social and cultural spaces which are taking place in Balige, the city which is on the edge of Lake Toba (Figure 1). It is located on Jalan Sisingamangaraja, the main street of the city. The area where the onan took place becomes the locus in this study. This research uses a mixed research method with qualitative and quantitative research. Through the primary and secondary theory of research, the researchers understand how the city space changes and how onan still exists in the midst of such changes. The research method begins with collecting data through the city and all the activities in onan. There are two kinds of onan activities, first is everday onan which take place in traditional market, secondary is weekly onan which happen every day on the street. Next method is collecting references and history about onan struggling in Balige and conducting interviews with some of local communities, the visitors, the buyers and related agencies.

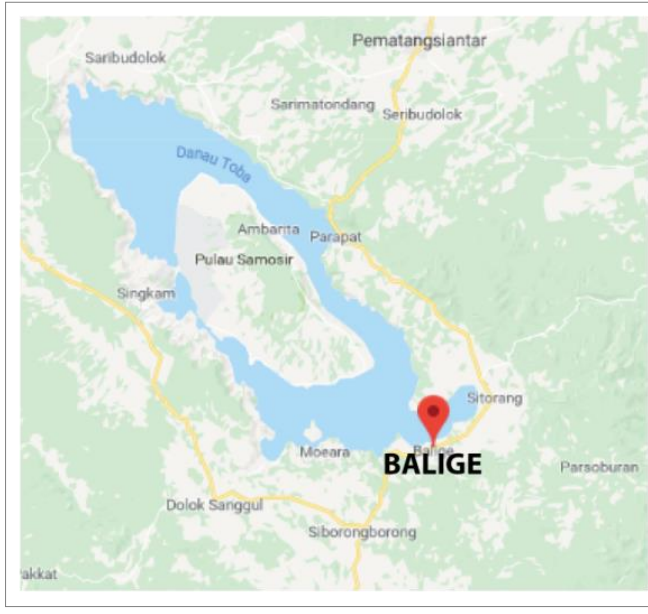

Figure 1 Location of Balige

\section{RESULT AND DISCUSSION}

\subsection{History of Balige}

Balige was officially part of Toba Regency in 1998 and was set as the capital city of Tobasa Regency in 2004. Geographically, Balige is located in strategic area. It is accessible from surrounding Tapanuli region and close to Lake Toba, Silangit International Airport. Historically, Balige was center of the Batak village. Some of the Batak clans are derived from this area. As one of origin areas of Batak people makes it be known as "Bona Pasogit (means hometown)". All the monuments, king tombs and the old house strengthen the city image as hometown of Batak people. The population of the area is dominated by Batak that live with their principles and values of their Batak cultures. Balige also known as a center of education for its surrounding. Parents send their children to study in the city, for the best schools in the region are here. In this city, there is also Balige Hospital which becomes healt care centre in Balige and surrounding.

\subsection{Transformation of Space that Change the Image of Balige}

Modernity is considered as a new part in the creation of spaces that uphold the power of science as a way out of the problem of space in the city. Modernity elevates reason and directs it to certain universal truths. Modernity does not want to look back, but it looks ahead and looks for new things and offers continuous, innovative and dynamic changes. Featherstone [7] argued that modernity is no longer only seen in the social context of transformation but is also seen in social relational contexts and social spatial contexts. According to him, the spaces in the parts of the world have become modern in many ways. Clifford [1] said that globalization allows distant places to access and affect the local. Through the commodities they are 
practiced in the form of information technology, the construction of shopping centers (malls and supermarkets), and the value and meaning in a wider network outside the location.

Undeniable, the determination of Lake Toba area by the central government of Indonesia as 10 national tourist destinations has expanded the opportunity of modernity into the region. Various models of successful tourism-based development in other regions are as glance and applied in this area. The phenomenon of modernity has also been presented in Balige and affects the city space namely Sisingamangaraja Street, Lumban Bulbul Area, and Lumban Silintong village (Figure 2). The city is known as the concentration of the transformation of the local values.

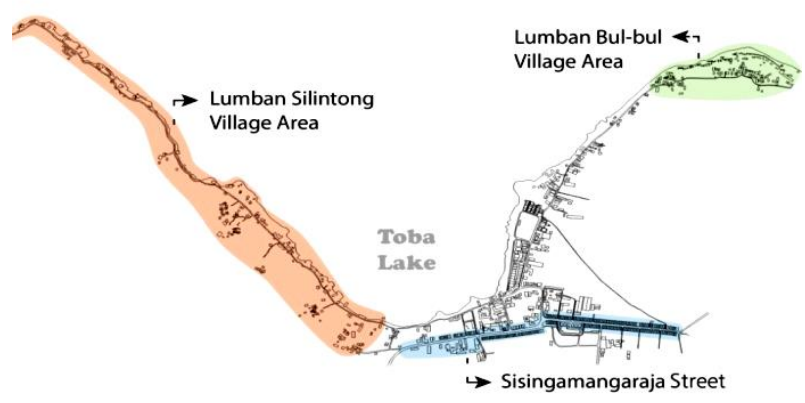

Figure 2 The locus of transformation in Balige

\subsubsection{Sisingamangaraja Street}

Sisingamangaraja Street is the main street in Balige. The road is a cross-entry to and exit from Balige city. As a main street, community activity centres are focused here. The consequences are that the business and the hustle centres continue to grow and thrive on this street.
The representation of Balige is shown along here. The commercial spaces such as shophouses, banks, finance companies, insurances, hotels, cafés, restaurant, and mobile phone shops are growing. Modern technology accelerates the inclusion of values and cultures to diminish traditions and replaces them with new ones. The value of space will appeal to the modernity. Government supports the capitalism as a factor that triggeres the spread of modernity in the city space. Gathering or mixing culture, even cultural competition are emerged.

In this street, the use value of living activity is blended with exchange value. However the use value of the Balige community in Sisingamangaraja is decreasing. The spaces which have quality value and gathering people with their local value is also reduced. Only about $12.12 \%$ of 48 residential houses are remained in this street. There are 5 hotels among 396 buildings are built (Figure 3). So, commercial activities has dominated in $73 \%$ of alll buildings along the main road.

During the last few years, the space in Sisingamangaraja Street is filled with the large-sized billboard, and the advertisements of modern brands. The transition of land ownership from local communities to migrants made the destruction of old buildings and the creation of new buildings. About $20-30 \%$ of the buildings along Sisingamangaraja Street are sold to other owners. While most of the buildings are rented by land owners who reside outside the city to the capital owners to open their commercial business around this main street.
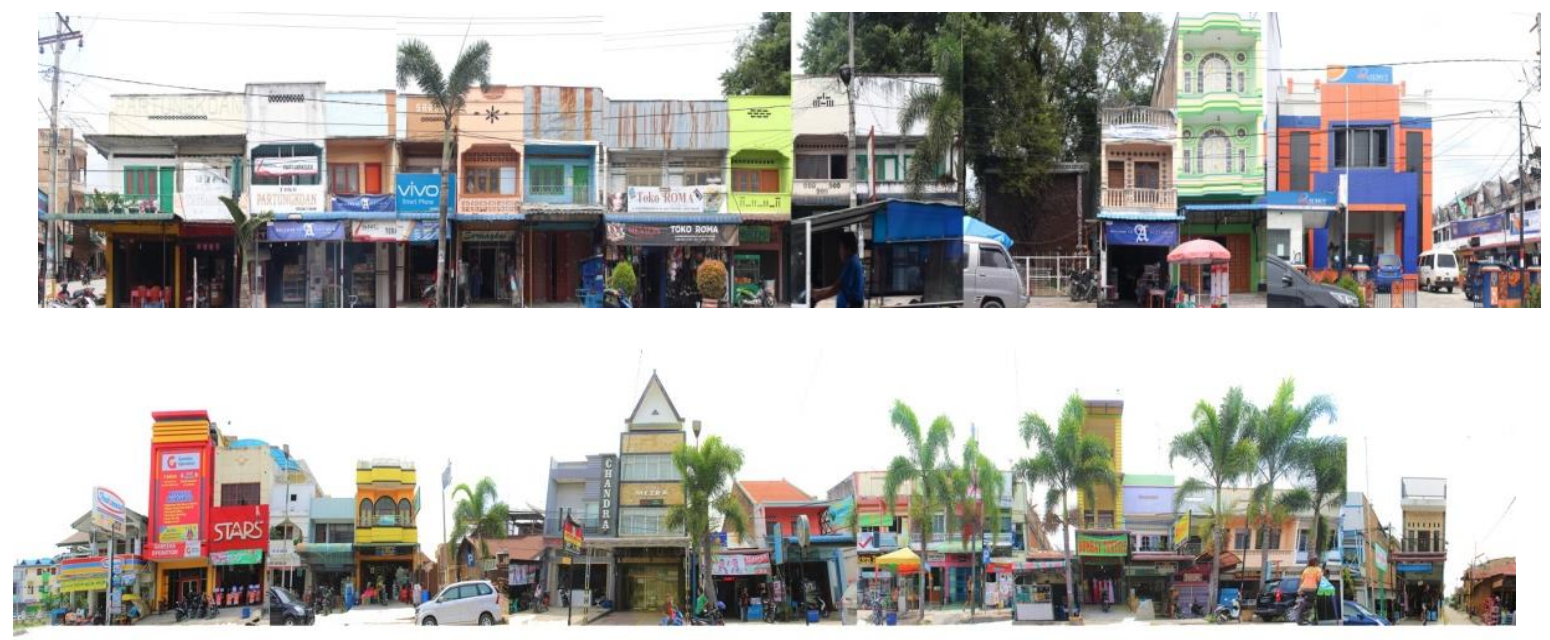

Figure 3 The transformation in Sisingamangaraja Street 


\subsubsection{Lumban Silintong Area}

Lumban Silintong is located on the edge of Lake Toba. The spread of commercial space has been created this area. Before the middle of 2015, the area was still dominated by local people's houses. People still use the their houses for living. The lands in most areas were functioned as agricultural lands. But in mid-2015 to the present, the $1.7 \mathrm{~km}$ lakeside village has undergone drastic changes. The open space that the public use to enjoy and utilize the lake water (use value) has been filled with new buildings with profit oriented (abstract space). There are 144 buildings along the left and right of the street, consisting of settlements, hotels, commercial buildings, church and offices (Table 1). Among the 56 commercial buildings there are 18 cafes built along the lakefront (Figure 4). The presence of the commercial building has transformed the face of Lumban Silintong space into the private space of the owner of the capital.

Tabel 1. The use of space in Lumban Silintong area

\begin{tabular}{|l|c|c|}
\hline \multicolumn{1}{|c|}{ Function } & $\begin{array}{c}\text { Number of } \\
\text { Buildings }\end{array}$ & Percentage \\
\hline Commercial Buildings & 50 & $35 \%$ \\
\hline Settlement & 86 & $60 \%$ \\
\hline Hotel (Inns) & 3 & $2 \%$ \\
\hline Goverment Office & 2 & $1 \%$ \\
\hline Church & 1 & $1 \%$ \\
\hline School & 1 & $1 \%$ \\
\hline Batak House & 1 & $1 \%$ \\
\hline Total & 144 & $100 \%$ \\
\hline
\end{tabular}

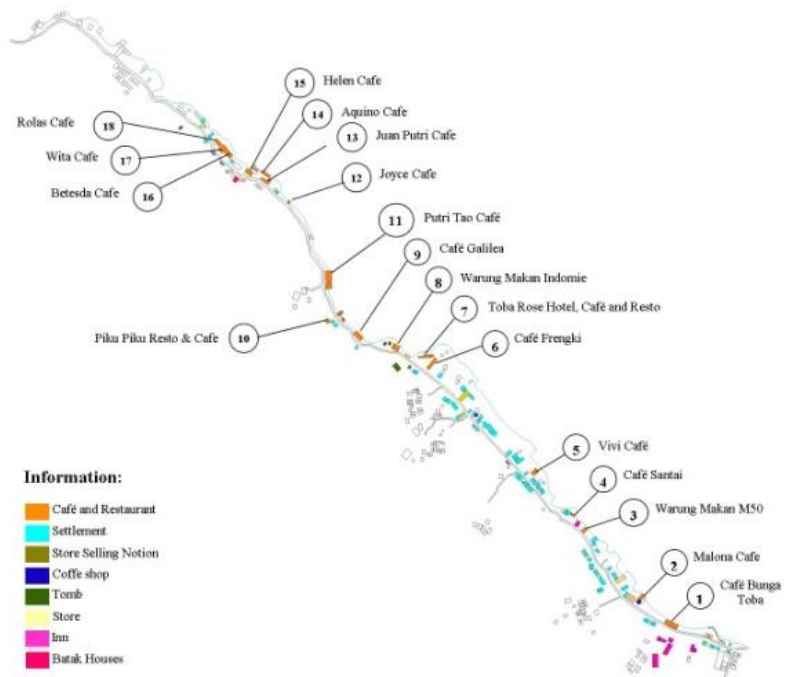

Figure 418 cafes located along Lumban Silintong area

\subsubsection{Lumban Bulbul Beach}

The setting of Lake Toba as the main destination in Indonesia is increasingly giving courage to the community in Lumban Bulbul to adopt a thriving lakeside tourism business from outside to this area. This causes Lumban Bulbul, a village located on the shores of Lake Toba, experience identity ambiguization. Previously, the space was area is still divided into the daily space of community (settlement), the yard of cattle, bamboo clumps, marshes and beaches. The community did daily activities, with value and house orientation facedthe street. In the backyard they were raising chickens, pigs and buffalo and behind the backyards were overgrown by bamboo clumps (Figure 5). But today, the local space has been transformed into commercial spaces. Beaches have become the main orientation in their various daily activities. Bambooplanted spaces are cut down, then the family built food and drink stalls. While the beach space becomes a recreation space consisting of various game rides and photos spot (Figure 6). The presence of modernity in Lumban Bulbul has destructed the local spaces. Government and peope who have money always money look for profits. Lumban Bulbul is produced as abstract space by the capitalism and government.

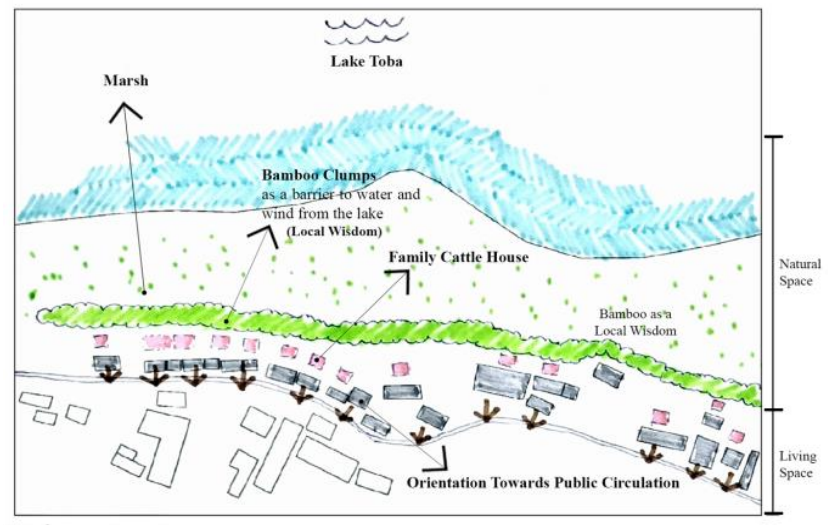

Figure 5 Lumban Bulbul before transformation

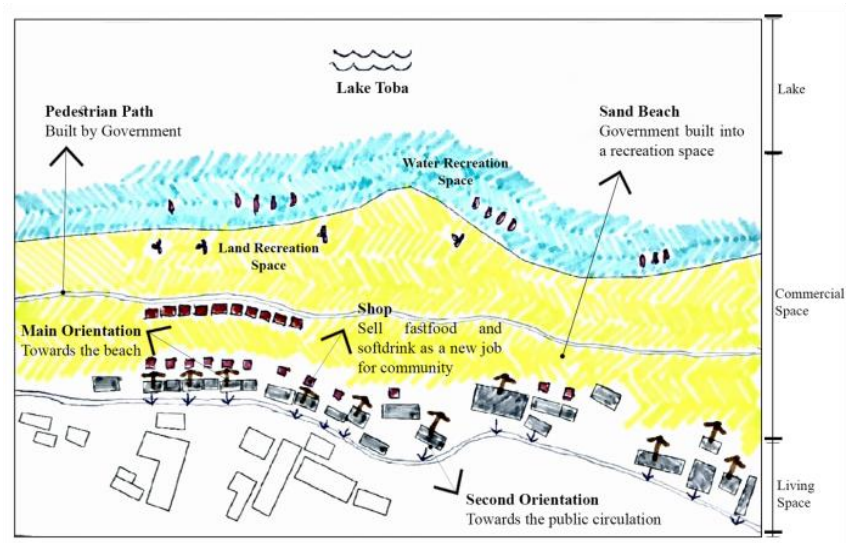

Figure 6 Lumbanbulbul after transformation 


\subsection{Onan's Strugle as Gathering Space}

The city was no longer built with 'natural power', but rather with capitalist power (Harvey and Castell) [1]. As discussed in a previous discussion, Balige has had changes both physically and nonphysically. Abstract spaces fills the city. Their presence slowly eliminate the local spaces. Modernity provides a very strong and promising encouragement to the community to accelerate the change. The changes have been dominated by capitalist intervention. Capitalist causes the city become the arena of class struggle. The city is characterized by scramble control over space. Capitalists worldwide have long scenarios of space exploitation.

Amids modernity in Balige, the city still provide a space showing how local value can still live in the middle of the city. The space that gives the opportunity of city diversity can be present simultaneously. The presence of the spaces in the city are indicated as an abstract space, meeting space, and a social space. One of them is the traditional market which is determined as the center of the city's economic life. In many cities in Indonesia, traditional markets are experiencing a breakthrough. The presence of modern markets constructed by capitalists has threatened the existence of traditional markets.

The markets typically are growing and developing as hubs of regional exchanges of goods and services,
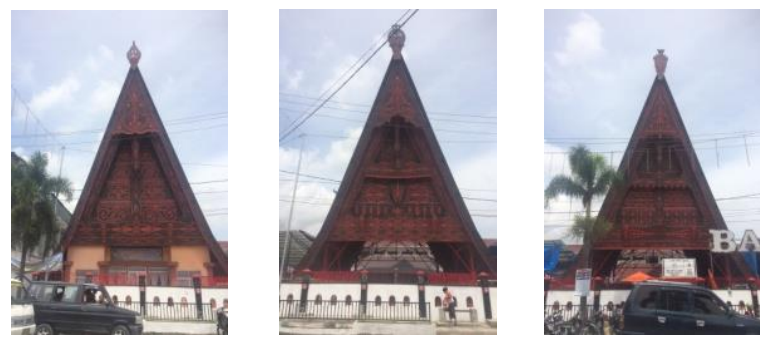

Figure 7 Balerong Buldings

The onan Balerong building in the figure above was built by the Dutch Colonial in 1938. The building was designed as meeting halls, entertainment centers and Batak Opera performance center. But in 1942, it was turned into a traditional market by Batak leaders because of its strategic location in the city center. In 1970, the market was developed, and it was characterized by the presence of shophouses around the onan Balerong complex. The existence of these buildings aim for tidiness and security markets. In 2004 to now the market has around 210 permanent kiosks in the second floor building on the back side of Balerong. But until today no merchants use the building because the design is not ergonomic. In 2017, local goverment conduct maintenance of the six buildings of Balerong, the gorga is repainted by which do not comply to the which generate various activities within the cities. In the market people buy and sell, exchange goods and services, also information and knowledge. The traditional markets have become an urban public spaces, places where city communities gather and build social relationships between them. Economically, the decline was also demonstrated by the increasing of people choose modern market rather than traditional market. If the decline of this traditional market continues, the function of market as urban social space will soon become obselete.

Onan (in Batak langunge), in the history of Batak is defined as market where people buy and sell materials of everyday life. Based on its operational time, onan is divided into daily markets and weekly markets. For weekly markets, the operating time depends on each region. In Balige has two onan.

Daily onan located on Sisingamangaraja Street, the main street of Balige city. Physically, the complex of daily market consists of six buildings with the traditional Batak Toba architecture, its name is balerong (Figure 7). The buildings have six traditonal style buildings, with similar dimension facades, and ornament gorga. Originally, the buildings are open without walls and have same materials, same structure iron, natural material paint, and distinctive ornament colors of Batak Toba ethnic.
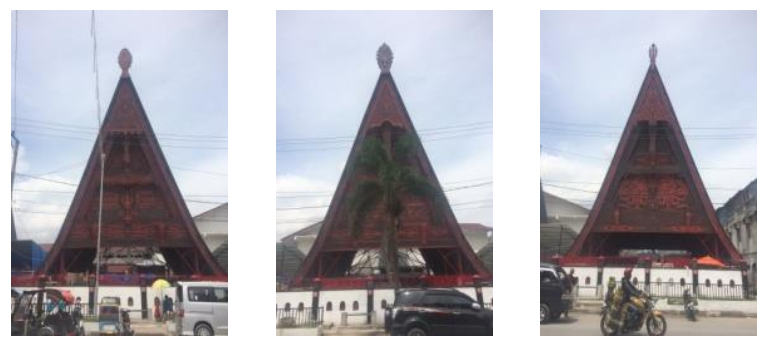

original characteristics and the typical of original design.

Some studies find that the traditional markets continue maintaining its distinctive uniqueness. It is awakened historically with the community that brought the market to life. In some cities, there are some traditional markets which act as major generators of city activities. Each traditional market has its meaning, identity, and history. Those make distinctive characters that distinguish them from other markets. The characters are the "spirit" of the market to continue surviving in the constellation of economy and the development of a city.

Onan Balerong Balige with its uniqueness of its Batak architecture exists until today. It acts as the center of the economic activities and a landmark of the city. 
The integrity of the cultural value of Batak that is represented through the presence of Onan Balerong six buildings presents the characteristic, identity, and the existence of city. Its performance captivates people. It is a melting place of local and modern activity public attention, especially on Friday when onan arrives. For them it is an important day, like a celebration.

The weekly onan is onan that happens in Friday every week and takes place on the street, along the line between onan Balerong to the Balige Port (Harbour). Although it has lasted from generation to generation, weekly onan is a day of light of the city and people wait it every week. People enthusiastically welcome the activity, and provide special time to be able to go to there. When the day arrives, the city becomes very crowded and densed. The Balige community, people from around the area, even from Samosir Island meet in the central area of Balige. The number of sellers from inside and outside the area have successfully transformed the sidewalk in front of the store and the $1.9 \mathrm{~km}$ long starting from Sisingamangaraja Street to Balige Port into selling spaces (Figure 8). Along the street the sellers peddle their trades. Each of them has its own place to present their trades (Figure 9). Some use tents to protect them and their trades. The sellers are not only hawking the companionship, but also bringing their families, and also getting acquainted and jokingly to visitors.

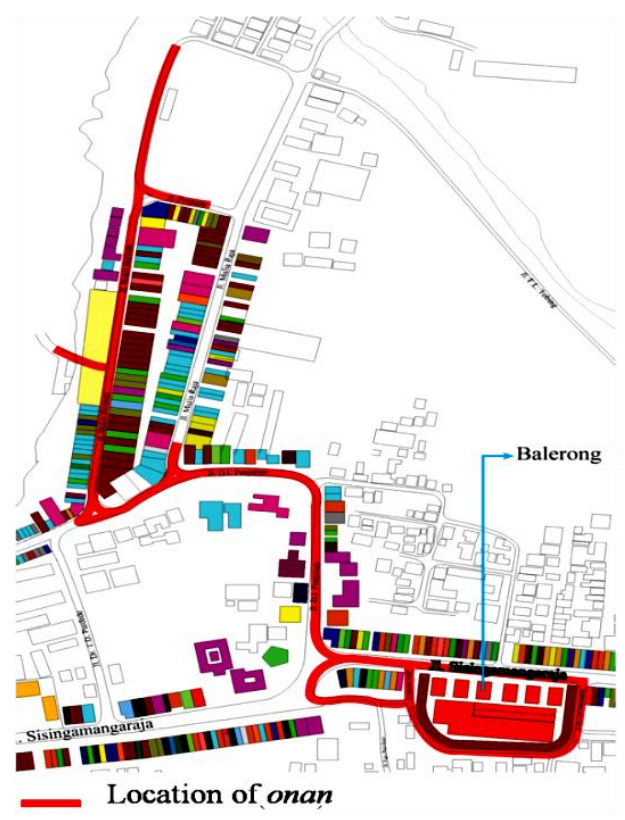

Figure 8 Onan presence along $1.9 \mathrm{~km}$

The interaction of people on onan every Friday creates gathering space that strengthen the existence of the market. The phenomenon is also found in the pedestrian paths in front of shophouses, the space produce social relations between sellers, buyers, shophouses owners, and gathers them and then their relations then produced the social space that can maintain the identity of the area [8].
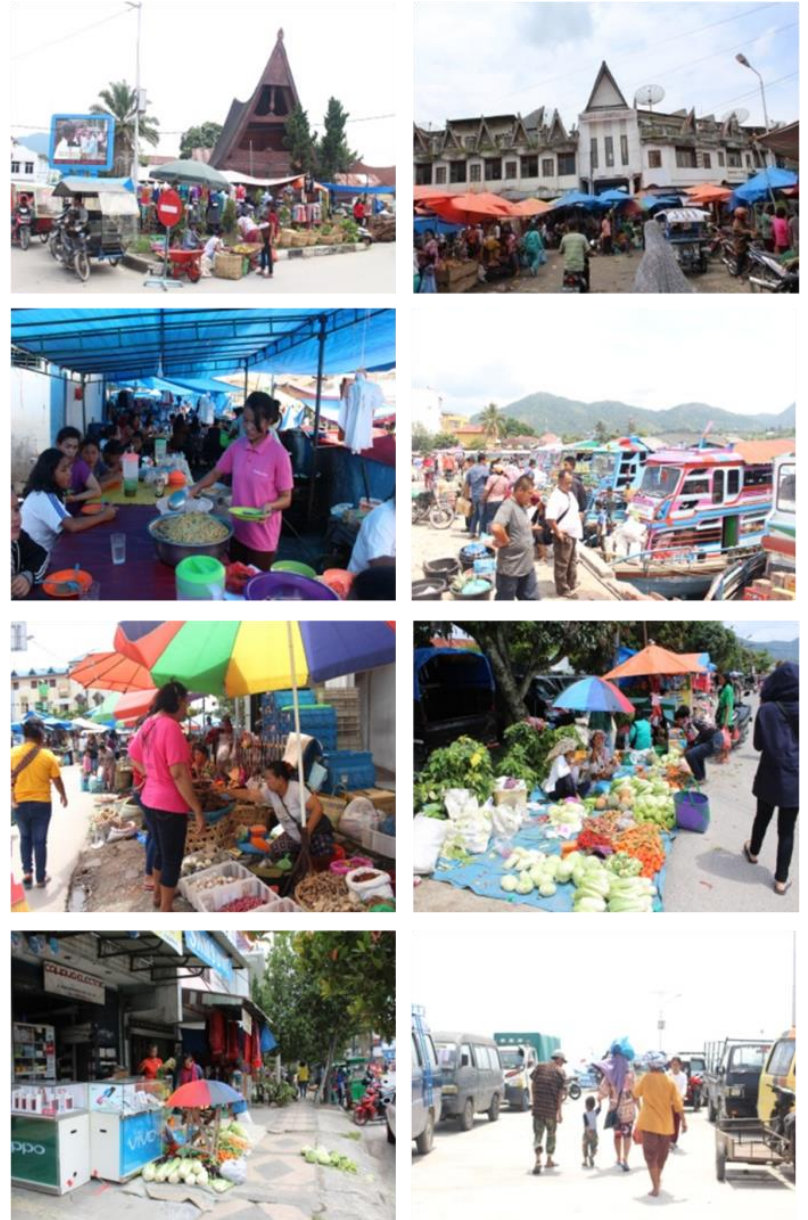

Figure 9 The atmosphere onan every Friday

The buyers are also mingle in these spaces. Onan activities is not just for economic interests, but it is an opportunity for vacation and of socializing. People who bring families come to the onan and accidentally met in the market and then share information. The local community from some villages in Balige discuss the update information and distribute the invitation of their family events. Moreover, this market are spaces for socializing, ties the relationship between families.

The existence of onan has created complexity in the space, where there are various layers of society with variety of cultures, behaviors, activities, values, gender, age, background, address and different interests, so that there is a unity of living heterogeneous (diverse) in it. Such complexity certainly carries many consequences, opportunities and challenges to the identity and image of the space. According to Wirth [1]globalization causes a loss of cultural diversity, where life in the city no longer knows one another. The condition that occurs in the onan is contrary to this. In onan Balige, daily and weekly, the dominance of modernity does not turn off the locality. Along the main street, Sisingamangaraja 
Street is evolved into shopping areas which facilitate varieties of needs, such as household furnitures, golds and jewels, mobile phones and accessories, computers, motors, instant foods and beverages; agricultural equipments and building materials. In addition Sisingamangaraja Street, the public offices such as insurance offices, banks, lodgings and hotels, bakeries, saloons, fast food restaurants, even mini market with modern style architecture exist together with Onan Balige and the merchants that take place in front of shop houses every Friday.

The activities of Onan is resilience space of urban community for doing their use value of living and struggling their life. Economic development makes the surrounding area of Onan Balerong complex be developed and changed into a commercial areas. The commercial activities have exchange values which was once the ghetto of communities lived with use values.

The transformation of spaces that occurs in Balige as presented in three important areas Sisingamangaraja Street, Lumban Silintong and Lumban Bulbul does not eliminate local values that live in the onan Balige, however they present together in the city.

\section{CONCLUSION}

Onan is a name for local selling-buying activities in Toba area. However, it has its meaning not only as the people activities, but also as the place. Onan always takes place where people can reach comfortly, which the potential spot in the city. Onan Balige is spread along street line from Balige Port to the city landmark, Balerong. The people built their own spaces, that fit to their needs and demonstrates the stage of the side by side small spaces, harmoniously by both seller and buyer groups together with new modern building surrounding. In fact, the space is created by the people, not by the architects or the planners. It becomes the gathering space for the people of the city and around. The stages of one day event is always struggling for gathering the people in Balige that is growing to be the modern one.

\section{REFERENCES}

[1] Barker, Chris. Cultural studies: Theory and practice. Sage, 2003.

[2] Madanipour, A, Design of Urban Space, John Wiley \& Sons, 1996.

[3] Lefebvre, Henri, The Production of Space, Blackwell Publishing, 1991.

[4] Gottdiener, Mark. The social production of urban space. University of Texas Press, 2010.
[5] Logan JR, Molotch HL, Urban Fortunes: The Political Economy of Place, University of California Press, 1987.

[6] Soja, Edward W, Thirdspace, Blackwell Publishers, Inc., 1996.

[7] Featherstone, Mike. "The flâneur, the city and virtual public life." Urban studies 35.5-6 (1998): 909-925.

[8] Siagian, Morida, Imej Ruang Sosial (Kajian Kes: Kawasan Kampung Keling di Medan Indonesia) Doctoral Thesis (Malaysia: USM), 2014. 